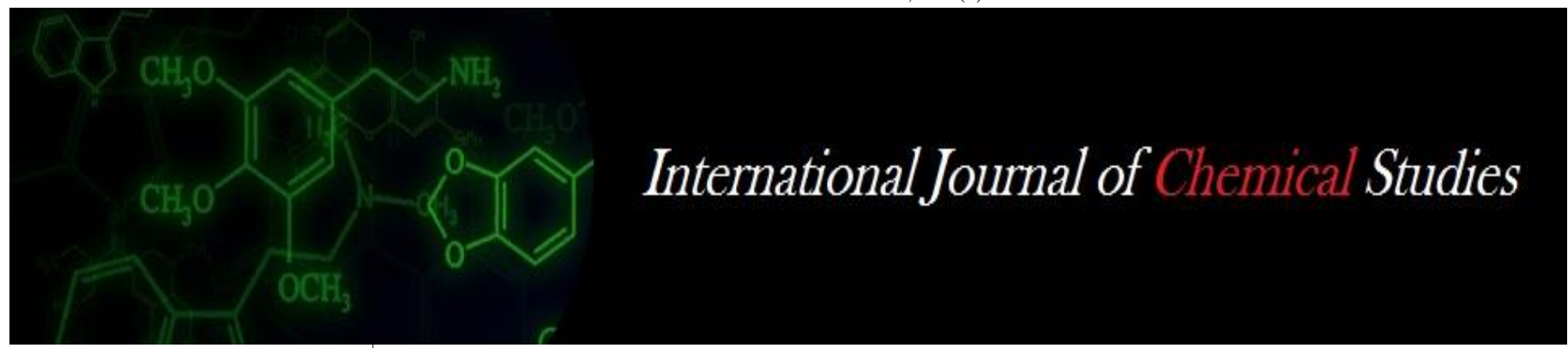

P-ISSN: 2349_8528

E-ISSN: 2321-4902

www.chemijournal.com

IJCS 2020; SP-8(4): 472-477

(C) 2020 IJCS

Received: 20-04-2020

Accepted: 18-05-2020

Nageswar Bandi

PhD Scholar, Department of

Farm Machinery and Power

Engineering Dr. NTR CAE

Bapatla, Angrau, Andhra

Pradesh, India

Venkata Reddy HK

PhD Scholar, Department of

Farm Machinery and Power

Engineering, Kelappaji College

of Agricultural engineering and

Technology Kau, Kerala, India

Dr. Manoj Mathew

Professor, Department of Farm

Machinery and Power

Engineering, Rice Research

Station, Moncompu, Alappuzha,

Kerala, India

Basavaraj Patil

PG(MTech), Department of

Farm Machinery and Power

Engineering, Kelappaji College

of Agricultural Engineering and

Technology KAU, Kerala, India

Amal Dev J

PG(MTech), Department of

Farm Machinery and Power

Engineering, Kelappaji College

of Agricultural Engineering and

Technology KAU, Kerala, India

Corresponding Author

Nageswar Bandi

PhD Scholar, Department of

Farm Machinery and Power

Engineering Dr. NTR CAE

Bapatla, Angrau, Andhra

Pradesh, India

\section{Design, development and testing of a paddy hill seeder}

\author{
Nageswar Bandi, Venkata Reddy HK, Dr. Manoj Mathew, Basavaraj \\ Patil and Amal Dev J
}

DOI: $\underline{\text { htps://doi.org/10.22271/chemi.2020.v8.i4h.10273 }}$

\begin{abstract}
Rice (Oryza sativa L.) is important leading food crop and it is widely cultivated in India. The farmers are facing problems due to lack of labour, time, inputs cost and also due to drudgery in work. Nevertheless, mechanization in paddy cultivation can boost higher productivity and considerably reduce the cost of production. Therefore, the present study was undertaken to design and develop a power operated paddy hill seeder in paddy cultivation. The power operated paddy hill seeder was developed and tested based on the, engineering and physical properties paddy seeds. The tests were conducted at Kelappaji College of Agricultural Engineering and Technology, Tavanoor, Kerala to evaluate the seed metering mechanism performance with different study parameters. The missing index and multiple indexes were less for the different combinations of study parameters (speed $1.5 \mathrm{kmph}$, cell size $9 \mathrm{~mm}$, Transmission ratio 1:1.7), (Speed $1.8 \mathrm{kmph}$, Cell size $9 \mathrm{~mm}$, Transmission ratio 1:1.7) and (Speed $1.8 \mathrm{kmph}$, Cell size $12 \mathrm{~mm}$, Transmission ratio 1:1.7). The quality feed index was $86.1,88.6$ and 91.1 respectively for above sequence of combinations of study parameters. The average field capacity of the paddy hill seeder was 0.22 ha h-1 and 0.26 ha h-1 with efficiency of $80.00 \%$ and $76.00 \%$ for forward speeds of 1.5 and 1.8 kmph respectively.
\end{abstract}

Keywords: Paddy hill seeder, seed metering mechanism, opening and closing mechanism, quality feed index, field efficiency

\section{Introduction}

Rice (Oryza sativa), is the world's most important cereal crop and is the staple food for more than half of the world's population. Also, the rice is ranked third in world cereal crop production after wheat and maize. About $90 \%$ of the world's rice (146.7 million ha of area with a production of 673.6 million tons of paddy) was cultivated and produced in Asia. India is the second largest producer of rice with 156 MT after China having 205.5 MT rice among countries in the world. Above facts revealed that rice is one of the most important crops in India and occupies $24 \%$ of gross cropped area of the country, with 45 million ha of cultivated area. (Anonymous, 2014) ${ }^{[1]}$.

The average rice yield in India is $3.5 \mathrm{t} \mathrm{ha}^{-1}$ compared to $4.5 \mathrm{t} \mathrm{ha}^{-1}$. However, there is drastic variation in average yield of rice in different states.

Table 1: Top 5 rice producing states in India (Sources: http://www.mospi.gov.in/statistical-year-bookindia/2016/177)

\begin{tabular}{|c|c|c|c|c|}
\hline S. No & State/ UT & $\begin{array}{c}\text { Rice } \\
(\mathbf{M T})\end{array}$ & $\begin{array}{c}\text { Area } \\
(\mathbf{M} . \mathbf{h a})\end{array}$ & $\begin{array}{c}\text { Average Yield } \\
(\mathbf{k g} / \mathbf{h a})\end{array}$ \\
\hline 1 & West Bengal & 14.71 & 5.38 & 2731.38 \\
\hline 2 & Uttar Pradesh & 12.22 & 2.62 & 2082.36 \\
\hline 3 & Andhra Pradesh+ Telangana & 11.56 & 3.80 & 3036.35 \\
\hline 4 & Punjab & 11.10 & 2.89 & 3837.94 \\
\hline 5 & Orissa & 8.28 & 4.16 & 1988.84 \\
\hline
\end{tabular}

With the present rate of growing population, India would require an estimated production of 120 million tonnes of rice per year by 2030 . The projected demand has to be met against the odds like declining land and water resource, scarcity of labour and costly inputs which are making rice cultivation too expensive. 
The cost of rice cultivation can be reduced and makes rice cultivation more profitable is the need to the farmers. In generally the rice crop is established by broadcasting, drilling and transplanting methods. The dry or pre-germinated paddy seeds of about $100 \mathrm{~kg} / \mathrm{ha}$ or more are sown by manual broadcasting. While dry paddy seeds are either manually broadcasted or drilled by tractor drills and animal powered drills on dry rainfed paddy lands. However, manual drum seeders are now popularly used for sowing pre-germinated paddy seeds on wetlands. The manual drum seeders sow about $35-40 \mathrm{~kg} / \mathrm{ha}$ of paddy seeds, which are less compared to $100-140 \mathrm{~kg} / \mathrm{ha}$ by manual broadcasting. Now, the mat seedlings are used for manual as well as mechanized transplanting. The land area for raising nursery can be reduced to about $100 \mathrm{sq}$. $\mathrm{m}$. for hectare compared to tenfold area required for root washed seedlings. The mechanized transplanting is popular since diverse types of machines are available in the market to suit the local requirements of the rice fields in upland and low land conditions. However, the mat seedling and transplanters have not gained much popularity due to the management of nursery and fields which are not established properly for easy accessibility of mechanical transplanters in spite of the advantages of controlling weeds. Mechanical transplanters have high initial cost; poor traction and shrinkage are other reasons for the lack of wider adoption in Indian conditions.

Direct seeding of dry and pre-germinated paddy seeds has gained popularity due to the direct establishment of plants without uprooting and transplanting which takes some time for plants to establish from physiological shocks caused due to uprooting. Also, the weeds are controlled successfully by applying suitable weedicides at appropriate growth stages of paddy. In dry seeding application of paddy in low wetlands, the water is drained systematically as the seeds starts sprouting and an early emergence of weeds are controlled initially and later the weeds are controlled by weedicides. Thus, direct seeding offers great advantage in the management of seed material, labour, cost and inputs management on the way to establish the rice crop without much differential difference in yield reduction compared to other rice establishing methods. The direct seeding of rice technique offers viable option to reduce the limitations of transplanted paddy. Direct seeded rice (DSR) was a common practice before green revolution in India, is becoming popular once again because of its potential to save water and labour (Gupta et al., 2006) ${ }^{[2]}$.

Direct seeded rice removes puddling and drudgery of transplanting as well as saves of water. The success of DSR mainly attributed to timely sowing, reduced cost of cultivation, seed rate, fertilizer, water and equal or higher yield as compared to transplanting. DSR is currently being practiced in China, Malaysia, Thailand, Vietnam, Philippines, and Sri Lanka. About 95\% of the rice grown in Sri Lanka is direct-seeded (wet- and dry-seeding) (Pandey and Velasco, 2002) ${ }^{[4]}$.

Nevertheless, the problems with existing seed drills are their unequal seed placement in a row, excess seed dropping, the ground wheels get stuck with soils which result in ground wheel slip or skid in loose soils. However, it is well known that seed drills for direct seeding have very high seed rates $(80-120 \mathrm{~kg} / \mathrm{ha})$ because of the non-availability of drills fitted with precise seed-metering mechanisms. In fact, in some parts of the country, high seeding rate resulted in nitrogen $(\mathrm{N})$ deficiency and caused a substantial reduction in grain yield (Mahajan et al., 2013) ${ }^{[3]}$. Even though the manual drum type direct seeders and tractor drills sow paddy seeds in lines but the distribution of seeds along the lines are not uniform and widely dispersed along the lines. Therefore, the placement of paddy seeds in correct quantity in hills spacing is desired to achieve optimum plant population.

Therefore, it is imperative to design an appropriate precision hill seeder for sowing precision number of seeds to maintain correct seed rate and at correct spacing to attain correct population. The Yanji mechanical transplanter is widely adopted in Kerala since it is a single ground wheel driven traction machine with a float supporting most of its weight. It can easily maneuver in rice fields of low wet lands having soils with poor traction in addition to its simplicity and low cost. Since majority areas of rice in Kerala are under wetlands, it is prudent to develop a precision paddy hill seeder since line seeding in hills improves easy removal of weeds and wild rice, application of agro chemicals for weed control and for protecting rice crop against the incidence of frequent and large scale pests and diseases. In order to overcome the problems stated above and to mechanize and enhance production and productivity of wetland rice cultivation in traction poor soils, a precision paddy hill seeder attachment was developed for Yanji Make rice transplanter.

\section{Materials and Method}

\section{Design of power operated paddy hill seeder Design features and specifications}

The paddy hill seeder was developed to suit paddy crop and to work in various types of soil and their moisture conditions. The crop parameters measured during the design of seeder are furnished in table. Based on the crop parameters power operated paddy hill seeder was designed taking each parameter into consideration.

Table 2: Physical dimensions of pre-germinated paddy seeds

\begin{tabular}{|c|c|c|c|}
\hline \multirow{2}{*}{ Sl. No } & \multirow{2}{*}{ Dimensions/ Varity } & Uma & Jyothi \\
\cline { 3 - 4 } & & \multicolumn{2}{|c|}{ Mean \pm SD, mm } \\
\hline 1 & Length (mm) & $7.67 \pm 1.07$ & $8.35 \pm 1.16$ \\
\hline 2 & Width (mm) & $3.19 \pm 0.23$ & $3.08 \pm 0.26$ \\
\hline 3 & Thickness (mm) & $3.04 \pm 0.33$ & $2.86 \pm 0.44$ \\
\hline 4 & Equivalent diameter (mm) & $4.20 \pm 0.28$ & $4.19 \pm 0.31$ \\
\hline 5 & Geometric mean diameter (mm) & $4.20 \pm 0.23$ & $4.19 \pm 0.24$ \\
\hline 6 & Sphericity (\%) & $0.546 \pm 0.04$ & $0.501 \pm 0.04$ \\
\hline 7 & Surface area (mm $\left.{ }^{2}\right)$ & $46.997 \pm 0.05$ & $47.575 \pm 0.05$ \\
\hline 8 & Aspect ratio & $0.416 \pm 0.04$ & $0.368 \pm 0.051$ \\
\hline 9. & Bulk density & $583.34 \pm 3.02$ & $552.11 \pm 4.14$ \\
\hline 10. & True density & $1250 \pm 35.28$ & $1095 \pm 32.13$ \\
\hline
\end{tabular}


The general design specifications of the paddy hill seeder are given in Table 3 .

Table 3: Design Specifications of paddy hill seeder

\begin{tabular}{|c|c|c|}
\hline Sl. No. & Particulars & Values \\
\hline 1 & \multicolumn{2}{|l|}{ Over all dimensions } \\
\hline & Length $\times$ width $\times$ height, $\mathrm{mm}$ & $2500 \times 2131 \times 1300 \mathrm{~mm}$ \\
\hline 2 & \multicolumn{2}{|l|}{ Specifications of prime mover } \\
\hline & i. Make and model & $\begin{array}{c}\text { VST SHAKTI YANJI } \\
\text { 170F Single Cylinder Air Cooled Diesel }\end{array}$ \\
\hline & ii. Power source, hp & 05 \\
\hline 3 & Type of attachment & Mounted hill seeder \\
\hline 4 & Number of rows & 8 \\
\hline 5 & Row spacing, mm & $230 \mathrm{~mm}$ \\
\hline 6 & Plant spacing, $\mathrm{mm}$ & 90 to $200 \mathrm{~mm}$ (Adjustable) \\
\hline 7 & Nominal working width, $\mathrm{mm}$ & 1700 \\
\hline \multirow[t]{5}{*}{9} & \multicolumn{2}{|l|}{ Metering mechanism } \\
\hline & i. Type of seed metering mechanism & Cell feed vertical roller type \\
\hline & ii. source of power for driving metering mechanism & PTO \\
\hline & iii. Number of seed metering disc & 8 \\
\hline & iv. Diameter of metering disc, $\mathrm{mm}$ & 70 \\
\hline \multirow[t]{4}{*}{10} & \multicolumn{2}{|l|}{ Hoppers } \\
\hline & \multicolumn{2}{|l|}{ Seed hopper } \\
\hline & i. Shape & Trapezoidal section \\
\hline & ii. Capacity, $\mathrm{m}^{3}$ & 0.20 \\
\hline 11 & Weight of hill seeder, kg & 60 \\
\hline 12 & \multicolumn{2}{|l|}{ Power transmission } \\
\hline & i. The power from PTO to seed metering and hopper metering mechanisms & Gear box and chain sprocket to to metering shaft \\
\hline & ii. Speed ratio & $1: 1.7,1: 23,1: 0.95$ \\
\hline
\end{tabular}

1.1 Design of seed hopper

Design specifications of seed hopper are,

Length of box $=110 \mathrm{~cm}$

Top width of the box $=25 \mathrm{~cm}$
Bottom width of the box $=15 \mathrm{~cm}$

Height of the box $=30 \mathrm{~cm}$

Angle of repose $=39^{\circ}$

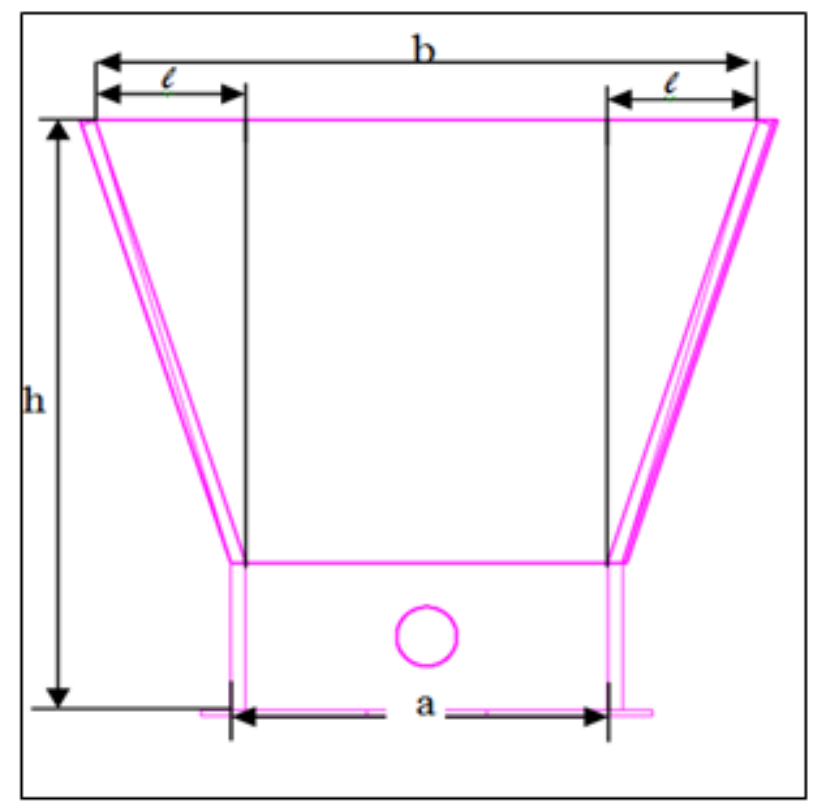

Fig 1: Cross sectional view of seed hopper

\subsection{Design of metering mechanism}

For hill dropping paddy seeds, a roller type cell mechanism was selected. The roller cell was designed on the paddy dimensions. The 3 to 5 numbers of paddy seeds were to be picked by cell type roller per dropping cycle. The paddy grain size was determined as per section grain length $7.2-8.3$ and thickness $2-2.3$. 


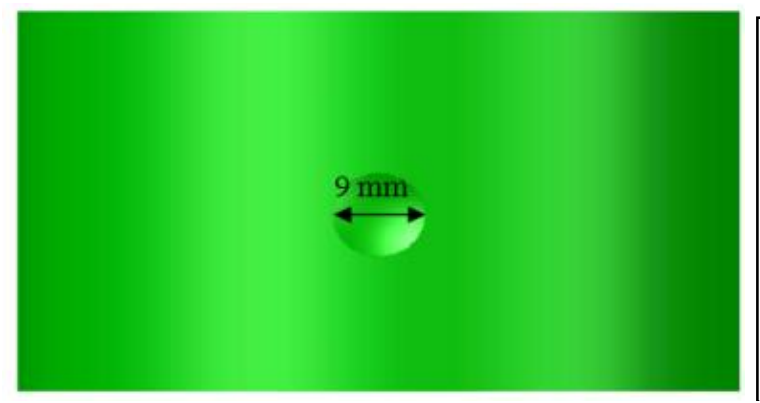

a. Top view

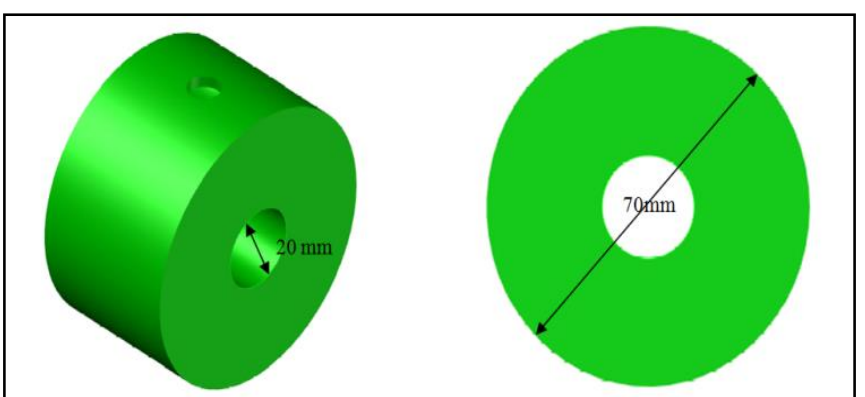

c. Side view

Fig 2: Cross sectional view of seed metering roller (vertical cell type)

\subsection{Design of transmission}

\subsubsection{Kinematics of gear and chain drive}

$\mathrm{N} 1=$ Speed of the driver at input shaft in rpm

$\mathrm{N} 2=$ Speed of the driven at output shaft in rpm

$\mathrm{N} 3$ = Speed of the driver at output shaft (linked to seed hopper metering screw) in rpm

$\mathrm{N} 4$ = Speed of the driven at seed hopper metering screw shaft in rpm

$\mathrm{N} 5=$ Speed of the driver at output shaft (linked to seed metering shaft) $\quad$ N6 $=$ Speed of the driven at seed
$\mathrm{T} 1=$ Number of teeth on the driver at input shaft $\mathrm{T} 2=$ Number of teeth on the driven at output shaft T3 $=$ Number of teeth on the driver at output shaft (seed hopper Metering screw)

$\mathrm{T} 4=$ Number of teeth on the driven at seed hopper metering screw shaft

T5 $=$ Number of teeth on the driver at output shaft (linked to seed metering shaft)

T6 $=$ Number of teeth on the driven at seed metering shaft metering shaft in rpm

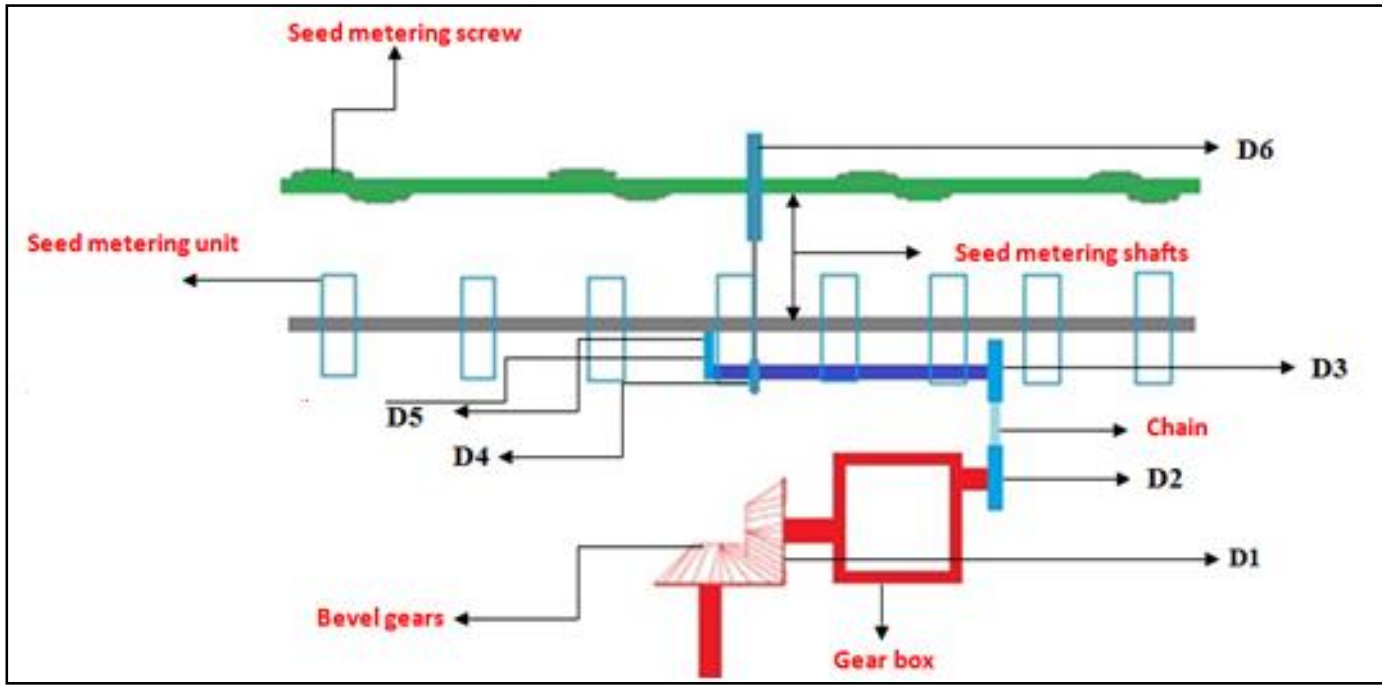

Fig 3: Power transmission system

\section{A. At seed metering shaft}

1. For 1:1.7 gear ratio (Low speed)

$\mathrm{T}_{1}=17, \quad \mathrm{~T}_{2}=29$

Velocity ratio,

$\frac{N_{1}}{N_{2}}=\frac{T_{2}}{T_{1}}=\frac{29}{17}=1.7$

Therefore,

$\mathrm{N}_{1=} 1.7 \mathrm{~N}_{2}$

2. For 1:1.2 gear ratio (Medium speed)

$\mathrm{T}_{1}=21, \quad \mathrm{~T}_{2}=26$

Velocity ratio,

$\frac{N_{1}}{N_{2}}=\frac{T_{2}}{T_{1}}=\frac{26}{21}=1.2$

\section{For 1:1.2 gear ratio (High speed)}

$\mathrm{T}_{1}=24, \quad \mathrm{~T}_{2}=23$

Velocity ratio,

$\frac{N_{1}}{N_{2}}=\frac{T_{2}}{T_{1}}=\frac{23}{14}=0.95$

Therefore,

$0.95 \mathrm{~N}_{1=} \mathrm{N}_{2}$

\section{At seed hopper metering screw}

$\mathrm{T}_{5}=14, \quad \mathrm{~T}_{6}=36$

$\frac{N_{5}}{N_{6}}=\frac{T_{6}}{T_{5}}=\frac{36}{14}=3$

Therefore,

$\mathrm{N}_{5=} 3 \mathrm{~N}_{6}$

Therefore,

$\mathrm{N}_{1=} 1.2 \mathrm{~N}_{2}$ 


\subsection{Design of opening and closing mechanism}

For paddy hill seeder, an opening and closing type mechanism was selected. The mechanism was designed based on the to and fro motion of a seed metering shaft. This is designed on the aim to reduce the scattering of seeds and maintain the distance between the hills.
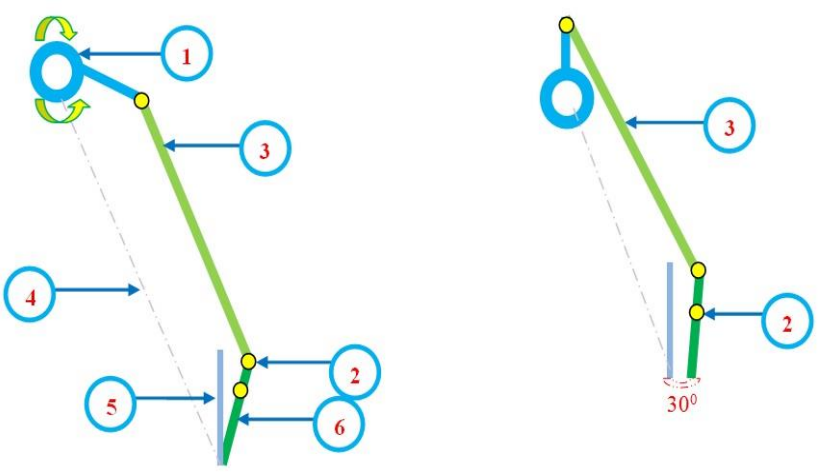

\begin{tabular}{|c|c|c|c|}
\hline No. & Description & No. & Description \\
\hline 1 & Seed metering roller & 4 & Fixed link \\
\hline 2 & Hinge points & 5 & Seed delivery tube \\
\hline 3 & Lifter arm & 6 & Opening and closing latch \\
\hline
\end{tabular}

Fig 4: Opening and closing mechanism of seed tube for dropping seeds

\section{Development of paddy hill seeder}

A proto type of paddy hill seeder was developed with design dimensions determined. The constructional detail of the paddy hill seeder is presented below.

\subsection{Constructional details of paddy hill seeder}

The seed hopper is constructed with MS sheet metal of thickness one $\mathrm{mm}$ and it was developed based on the above design parameters

\subsection{Seed tube}

The seed tube of $25 \mathrm{~mm}$ diameter was selected to the seed hopper for the delivery chute to seed metering boxes. The height of tube was $200 \mathrm{~mm}$ and kept at an angle of 250 to the vertical.

\subsection{Seed metering mechanism}

A vertical cell type metering roller was designed and fabricated for paddy seeds. The seed metering disc was fabricated using $40 \mathrm{~mm}$ thickness and $70 \mathrm{~mm}$ diameter nylon roller having one semicircle shaped cell shown in Fig.1.2. The metering roller was mounted and rotated vertically.

The major dimensions of the oval shaped cell were $9 \mathrm{~mm}$. The width of the cell at the outer perfectly was $4 \mathrm{~mm}$ and decreases to $3 \mathrm{~mm}$ towards the centre depth. A single cell was made on the vertical roller the vertically mounted metering disc is rotated in a casing with a bottom chute to deliver the paddy seeds. The vertical cell metering roller was mounted on shaft of diameter $20 \mathrm{~mm}$. The cut off was provided to prevent multiples and for excess seed removal from the cell.

\subsection{Construction of power transmission system}

The power is transmitted from the drive shaft of the selfpropelled unit to bevel gear unit through a universal coupling supported by pedestal bearing supports. The gear ratio for bevel gear unit is $1: 1.3$ as shown in Fig. 1.3. The output of the bevel gear unit is coupled to a gearbox input drive. The speed can be varied from low, medium and high speeds by selecting suitable gear ratio by shifting a gear shift lever. The output of the gear box is transmitted to a counter shaft through chain and sprocket drive. The counter shaft drives the metering mechanism. The alternate opening and closing of the seed tube facilitates in dropping the seeds downwards without much scatter.

\subsection{Construction of main frame and attachment}

The main frame of the hill seeder that supports all other components of the paddy seeds. In this design, mild steel tube of $50 \mathrm{~mm} \times 50 \mathrm{~mm} \times 20 \mathrm{~mm}$ was used to give the required strength and rigidity, so that it can withstand all types of load during operation.

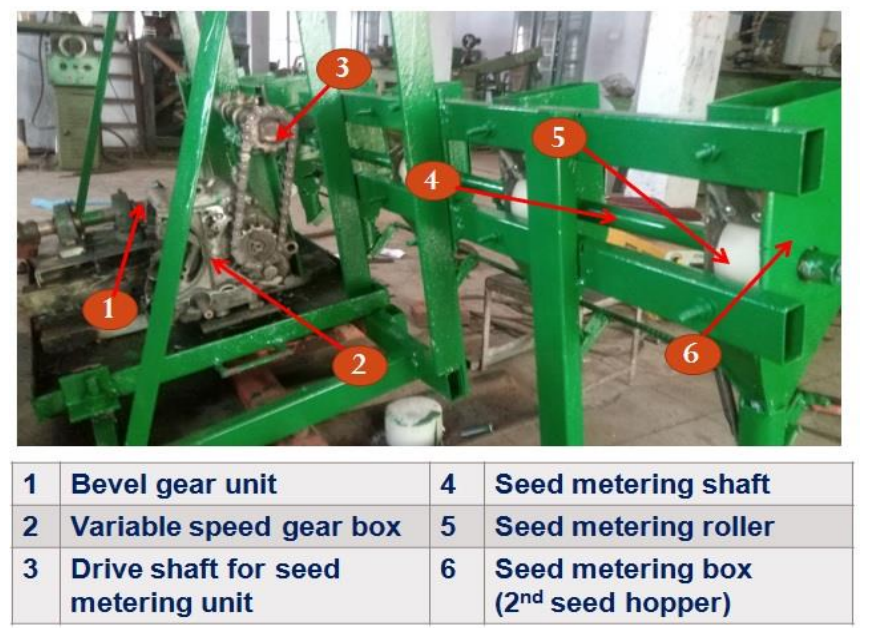

Fig 5: Construction of main frame and attachments

\section{Results}

The testing of paddy hill seeder was conducted in a lab for a combination of crop parameters viz., row to row spacing of $0.23 \mathrm{~m}$, hill to hill spacing of $0.09-0.20 \mathrm{~m}, 3$ to 7 seeds per hill, seed rate of $21-58 \mathrm{~kg}$ ha-1 when metering mechanism calibrated for different hill spacing's. The tests were conducted on sand bed to evaluate the seed metering mechanism performance with respect to spacing, seed rate, quality of feed index, multiple index, miss index, and seed damage at two different forward speeds (1.5 and $1.8 \mathrm{~km} \mathrm{~h}-1)$, two cell sizes and three transmission speeds (1:1.7, 1:1.2 and 1:0.95). The missing index and multiple index were less for the different combinations of study parameters (speed 1.5 $\mathrm{kmph}$, cell size $9 \mathrm{~mm}$, Transmission ratio 1:1.7), (Speed 1.8 $\mathrm{kmph}$, Cell size $9 \mathrm{~mm}$, Transmission ratio 1:1.7) and (Speed $1.8 \mathrm{kmph}$, Cell size $12 \mathrm{~mm}$, Transmission ratio 1:1.7). The quality feed index was $86.1,88.6$ and 91.1 respectively for above sequence of combinations of study parameters. The average field capacity of the paddy hill seeder was 0.22 ha h-1 and 0.26 ha h-1 with efficiency of $80.00 \%$ and $76.00 \%$ for forward speeds of 1.5 and $1.8 \mathrm{kmph}$ respectively. The cost of developed prototype mechanical hill seeder was Rs. 28573/

\section{References}

1. Anonymous. Reports. Directorate of Economics and Statistics, Department of Agriculture and Corporation, 2014.

2. Gupta CP, Herwanto T. Design and development of a direct paddy seeder. Agricultural Mechanization in Asia, Africa and Latin America, IS: 9164-1979: Guide for estimating cost of farm machinery operation's, New Delhi, 2006; 23(1):23-27. 
3. Mahajan G, Chauhan BS, Gill MS. Dry-seeded rice culture in Punjab State of India: lessons learned from farmers. Field Crops Research, 2013; 144:89-99.

4. Pandey S, Velasco L. Economics of direct seeding in Asia: patterns of adoption and research priorities. In Direct seeding: research strategies and opportunities International Rice Research Institute Los Baños, Philippines 2002, 3-14. 